\title{
The role of extension and forest characteristics in understanding the management decisions of new forest owners in Ireland
}

\author{
V. Upton ${ }^{\mathrm{a}}, \mathrm{M}$. Ryan $^{\mathrm{a}, *}, \mathrm{~K}$. Heanue $^{\mathrm{c}}$, Á. Ní Dhubháin ${ }^{\mathrm{b}}$

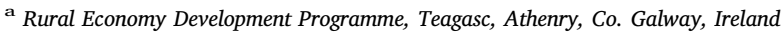 \\ b Forestry Section, School of Agriculture and Food Science, University College Dublin, Dublin 4, Ireland \\ c Business Planning and Performance Evaluation Department, Teagasc, Athenry, Co. Galway, Ireland
}

\begin{abstract}
A B S T R A C T
Many European countries have seen significant changes in forest ownership structure, with the emergence of a cohort commonly referred to as new forest owners, mainly within the non-industrial, private forest (NIPF) owner group. The drivers of this change differ between countries but these owners frequently lack an existing knowledge base to draw on regarding forest management decisions and practices and may possess different objectives to traditional owners. As a result there is uncertainty concerning the management intentions of these owners. The provision of extension services is a recognised approach to supporting decision-making by NIPF owners but there have been relatively few studies that have sought to quantify the effectiveness of such initiatives in terms of management outcomes. In addition to measuring the outcome of extension initiatives, exploring the positive or negative outcomes can assist with the design of future initiatives. Ensuring that such initiatives are designed for appropriate phases in the forest life-cycle is important. This paper reports the results from a number of surveys that sought to explore the impact of an extension initiative, a thinning demonstration, on actual management outcomes and what characteristics of owners and their forests might explain observed management decisions. A retrospective pre-post test questionnaire was used at the demonstration to capture knowledge impacts and management intentions. A follow up survey was conducted 18 months later to investigate what, if any, practices had been undertaken. Data from a national household survey of land owners were also analysed to investigate whether the observations from the demonstration had significance for the wider population. The results suggest that the demonstration was successful in imparting knowledge to forest owners both in terms of self-reported learning and actual management outcomes. However, from an Irish perspective management decisions are dominated by forest age as the majority of the private estate is still in its first rotation. This presents a challenge to extension service personnel and to research seeking to explain management practices at a national level.
\end{abstract}

\section{Introduction}

The decision-making of private forest owners can have significant impacts beyond the borders of their property. While this observation is commonly made in reference to non-commercial, environmental benefits, it is also true for industries that rely on timber production. However, changes in the ownership structure and the emergence of new owner types which is one of the defining aspects of private forest ownership in modern Europe (Hogl et al., 2005; Follo et al., 2016) is raising concerns about the level of management being undertaken in private forests (Wiersum et al., 2005; Ní Dhubháin and Greene, 2009). In particular, the harvesting behaviour of these new owners is attracting attention given that demand for wood in Europe is expected to increase.

Decision-making by non-industrial private forest (NIPF) owners is influenced by a variety of factors including market drivers, policy variables, owner characteristics and plot conditions (Beach et al., 2005). As laws and policies vary across countries, identifying universal factors that explain forest owner decision-making is difficult. Variations in owner demographics and forest characteristics and conditions also complicate the interpretation of owner behaviour. In reviews of European and US studies into decision-making by NIPF owners, conducted by Beach et al. (2005) and Amacher et al. (2003), one of the few apparently consistent findings from this body of research is that education and access to technical support and extension services has a positive impact on the probability of engaging in active forest management,

\footnotetext{
* Corresponding author.

E-mail addresses: vupton@gmail.com (V. Upton), mary.ryan@teagasc.ie (M. Ryan).
} 
such as thinning and harvesting. Given that timber availability from non-industrial private forest lands is strongly influenced by the objectives of individual owners (Pattanayak et al., 2002; van Putten and Jennings, 2010), access to extension services can both provide essential information required by forest owners and, also, influence the formation of a normative belief system around what is considered "proper" management (Wild-Eck et al., 2006).

The increasing diversity amongst private owners and the role of extension in addressing their needs means that there is increasing focus on how and from whom these services should be delivered. The traditional linear form focuses on the delivery and receipt of knowledge between a forestry professional and forest owner although this interaction can be complex. In analysing such interactions, Virkkula and Hujala (2014) found that the delivery and receipt of information generally followed the linear form but that owners would typically engage and guide the conversation if they desired. Kuhns et al. (1998) showed that forest owners expressed a preference for personal contact with knowledge transfer professionals. Peer-learning has also been shown to be effective in encouraging forest owners to engage in management and develop their knowledge levels (Ma et al., 2012).

Although the provision of knowledge and education is recognised as important in assisting NIPF owners there have been relatively few attempts at investigating and quantifying the effectiveness of extension activities in influencing management practices. Ireland offers an interesting case study for such investigations for a number of reasons. First, private forestry in Ireland is dominated by new forest owners, i.e. farmers, who have been offered financial supports (co-funded by the EU) since the 1980s to establish forests on previously agricultural land. The Irish Forest Service estimates that the private forest estate contained 342,296 ha in 2012 , with over $70 \%$ of this area established since 1980 with the aid of public supports (Forest Service, 2013). These landowners were primarily farmers who planted part of their holding and would have been engaging with forestry for the first time (Duesberg et al., 2014). Thinning typically commences in Ireland between fifteen and twenty years of age in productive forests, therefore much of the private estate is at the age of first thinning. Farm/private forestry is relatively new to Ireland, in contrast to the situation that prevails in other European countries which have a long tradition of forestry and where many forest owners would traditionally have had access to a bank of inherited practical management knowledge and a traditional engagement in harvesting (Kuuluvainen et al., 1996). However, the structural changes that are currently being witnessed in Europe, including the increase in new forest owners, mean that the potential knowledge gap that Irish forest owners are experiencing may be an increasing feature of private forest ownership in general in Europe. These new-owners may possess more multifunctional objectives for their forests as reflected in the intensity of their harvesting intentions (Blanco et al., 2015). The engagement of forest owners in harvesting has also a particular relevance in Ireland as there are ambitious targets to expand the Irish forest estate and annual harvest to support the indigenous timber-processing industry and to produce other forest-related benefits. This includes a doubling of timber harvesting in the next two decades from its current rate of approximately four million $\mathrm{m}^{3}$, with almost all of this increase forecast to come from the private estate (Phillips et al., 2016). These forecasts assume that forests will be managed in a similar manner to those of the state forestry company, which generally include regular thinning and a clearfell system. Although the planning and establishment of these grant-aided forests is generally contracted to professional foresters, the cost of which is covered by grants, once forests are established successfully, there are no obligations for owners to manage their forests for a given purpose. There are already concerns that the lack of forest knowledge and tradition amongst these new owners means that they are often not confident about undertaking potentially risky harvesting operations (both economically and silviculturally) and instead may opt not to thin their forests. This is despite the fact that timber production is a significant management objective for them (Ní Dhubháin and Greene, 2009).

Forestry extension services, undertaken by Teagasc the state agriculture and food development authority, have been evolving in Ireland to meet the challenges that the developing private forest estate and its new owners present. In addition to offering advice on an individual face to face basis and through demonstration events, advisors actively support the development of producer groups at a local level. Thus, Irish forestry extension services operate through linear knowledge transfer, peer-learning and expert-led group demonstration. In recent years a considerable focus of this extension effort has been directed at forest owners and their harvesting behaviour. This focus has been supported by research findings that private forest owners who attend extension activities are more likely thin their forest (Ní Dhubháin et al., 2010) and that many owners are cognisant of their poor knowledge of management practices, particularly when it comes to harvesting decisions (Maguire et al., 2010). The need for extension activities is further highlighted by findings that even if owners intend to thin, many have a poor understanding of the optimal time for first thinning (Maguire et al., 2010). This is particularly relevant in Ireland, where storm damage is a common occurrence, and where delaying first thinning may increase the risk of endemic windthrow. Thus, forests should be thinned before they reach a critical height with respect to windthrow. Extension activities are, therefore, often targeted at those owners who have forests that have not yet reached this critical stage.

This paper describes a longitudinal study which aims to explore the effectiveness of a forest thinning demonstration through the use of a face to face retrospective pre-post test questionnaire administered after the demonstration event and a telephone survey conducted 18 months later. In particular, this study attempts to determine whether self-reported knowledge levels changed as a result of attending the demonstration and to track forest owner intentions to undertake forest management interventions. In addition, data from a nationally representative farm survey (which includes farm forest owners) was employed to explore the factors that influence management decisions more generally and to expand the findings of the longitudinal study.

\section{Methods}

\subsection{Longitudinal study}

The first stage of the longitudinal study was conducted at a forestry extension event which demonstrated the operations that need to be carried out in advance of undertaking the first thinning operation in a forest stand as well as the actual harvesting process. The event took place on a 6 ha private forest in County Roscommon in the west of Ireland. The demonstration was publically advertised but invitations were also sent to owners in the region whose forests were close to the stage of first thinning. The demonstration focused on planning and operational topics related to first thinning in conifer forests. These included the provision of access both in terms of the cutting of forest inspection and brash paths and forest road construction; the felling licence application process (forest owners in Ireland are legally required to have a licence in advance of felling) and basic timber measurement; and environmental, operational and contractual considerations around the timber harvesting process. In addition information about the lengths and sizes of logs required by the market, the relevant timber prices, how to market the timber and how to safeguard against the theft of logs from the forest were covered during the demonstration. Face to face interviews were conducted with all of the 36 owners who attended the demonstration. A retrospective pre-post test questionnaire (Davis, 2003) was used at the demonstration to identify whether the owners level of understanding of a topic and confidence to undertake management actions, or what is conventionally understood as the 'knowhow' type of knowledge (Polanyi, 1978; Jensen et al., 2007), had improved. Owners were also asked about their intentions in relation to future management actions. 
The retrospective pre-post test questionnaire sought to capture the self-reported knowledge, described as understanding, of participants on the eight planning and operational topics addressed in the thinning demonstration, before it took place and also after. Respondents could rate their understanding from 1 to 5 with the question presented in the following manner:

"Rate your level of understanding of the following topics before and after the demonstration:

Very little understanding about topic $=1$, basic understandingneed to know more $=2$, good understanding - would not be confident about putting it to use $=3$, good understanding-would be reasonably confident about putting it into use $=4$, very good understanding-would be very confident about putting it into use $=5^{\prime \prime}$.

A follow-on phone survey of the 36 attendees of the thinning demonstration was conducted 18 months later. Only 26 of the owners who had attended the demonstration took part in this follow-one survey; the remaining participants could not be contacted or did not want to participate in the follow-up. During the phone survey respondents were asked about the actual management practices, such as creating brash paths for access and surveying purposes and thinning, they had undertaken. They were also asked an open ended question about why they had not undertaken specific practices and their responses were recoded into categories.

The demonstration and phone surveys were based on a relatively small sample size and a combination of continuous and ordinal response data. Data, maintaining the original coding, were tested for normality, transformed and re-tested but were still not normally distributed. Therefore, the appropriate test to use for comparing mean score responses was the Wilcoxon Signed Rank Test for non-parametric data, which is the equivalent of the dependent $t$-test for parametric data. The full sample was used to test the pre- and post-event responses to examine the impact of the event on stated understanding. The phone survey sub-sample was divided into those who had implemented a management intervention and those who hadn't, to explore whether their stated changes in understanding differed. The average forest age of different cohorts was calculated to explore its importance in understanding management practices.

\subsection{National Farm Survey}

The Teagasc National Farm Survey (NFS) is an annual survey of farms in Ireland that uses a quota based on enterprise and size to achieve a representative sample of Irish farms with a standard output greater than $€ 8000$. The main NFS sample comprises 922 farms which, when weighted, represent 79,292 farms from the total farm population of 139,860 . This survey forms the basis of the Irish data contribution to the EU Farm Accountancy Data Network (FADN) database. A supplementary survey is conducted on a sub-sample of farms annually, a number of months after the main survey. Although the sample is smaller, a similar sampling frame is maintained. The 2012 supplementary survey included questions on forestry. There were 788 farmer respondents of which 85 were also forest owners.

The NFS collects data on a range of socio-demographic and economic factors. Respondents who had forests were asked a series of questions pertaining to their motivations for planting and their management practices. Respondents were also asked whether they had thinned their forest and for the reason if they had not. Data from the NFS were used to expand on the findings of the longitudinal survey and to investigate whether similar influencing factors could be identified in a national context.

For the NFS generated data, tests of normality were conducted on the continuous variables which were not passed. Thus, continuous variables were analysed using a Mann-Whitney-Wilcoxon test and the Pearson Chi-squared test was utilised for binary variables. Other variables are expressed as averages or proportions as identified. Similar to the thinning demonstration data, this sample was divided amongst
Table 1

Results of pre- and post-event mean understanding scores for full sample $(\mathrm{N}=36)$.

\begin{tabular}{llll}
\hline Topic & Pre-event & Post-event & P-value $^{\mathrm{a}}$ \\
\hline Access - internal and external & 2.48 & 3.97 & 0.000 \\
Felling licences & 2.42 & 4.13 & 0.000 \\
Basic pre-thinning measurement & 1.90 & 3.60 & 0.000 \\
Harvesting - operational issues & 2.07 & 3.79 & 0.000 \\
Timber categories & 2.00 & 3.93 & 0.000 \\
Timber security & 1.71 & 3.57 & 0.000 \\
Marketing and selling timber & 1.90 & 3.52 & 0.000 \\
How to go about thinning your forest & 2.19 & 4.03 & 0.000 \\
\hline
\end{tabular}

${ }^{\mathrm{a}}$ Wilcox signed ranks test.

owners who had thinned their forest and those who had not and differences between cohorts were tested statistically.

\section{Results}

\subsection{Demonstration and phone survey}

A full data set from the thirty-six respondents was achieved for the pre- and post-event understanding ratings. Respondents indicated an increase in their levels of understanding across all topics and, as a whole, a positive and statistically increase in self-reported understanding was identified. However, as shown in Table 1, while participants record that after the event they would be reasonably confident about putting their knowledge of felling licences and how to go about thinning into use, they recorded that they would be less confident about putting the other elements of the demonstration into use. It is interesting to note that amongst the lowest scoring issues pre-event were measurement and marketing timber, skills which experienced forest owners are likely to possess.

The follow-up phone survey 18 months later focused on the management actions that owners had undertaken since the demonstration or planned to take in the future. Owners were also asked about their advice requirements. The number of owners who had planned to create inspection paths and thin their forest after the demonstration and those who had actually undertaken the actions by the time of the follow-up survey are presented in Table 2. This shows a large proportion of participants that declared an intention to undertake management actions after the demonstration but the actual results are mixed.

Out of the 19 who planned to put in inspection paths after the demonstration, 10 had done so confirming the learning from the demonstration and confidence in that learning identified in the retrospective pre-test. Of the 14 respondents who had inspection paths (including those that had them installed in advance of the demonstration), 12 had installed them themselves and two were in management agreements with an external company that had undertaken the work. Nevertheless, a further 9 of those who said they planned to install inspection paths did not. Two respondents had thinned their forest but a further six were in the process of preparing and planned to undertake

Table 2

Management practices undertaken by owners before the demonstration, stated as planned during survey and actually undertaken 18 months later $(\mathrm{N}=26)$.

\begin{tabular}{llll}
\hline & Yes & No & No answer \\
\hline Inspection paths & & & \\
Already undertaken & 4 & 20 & 2 \\
Planned after demo & 19 & 3 & 4 \\
Undertaken after 18 mths & 14 & 11 & 1 \\
Thinning & & & \\
Already undertaken & 0 & 26 & 0 \\
Planned after demo & 18 & 5 & 3 \\
Undertaken after 18 mths & 2 & 24 & 0 \\
\hline
\end{tabular}


Table 3

Average age of forests for owners by thinning response.

\begin{tabular}{lll}
\hline Response & $\mathrm{n}$ & Ave. age of forest \\
\hline Has thinned & 2 & 20 \\
Planning in next 6 months & 6 & 15.5 \\
Too young & 12 & 13.3 \\
Windthrow/not productive enough/access & 5 & 19.75 \\
Lack of information & 1 & 15 \\
N & 26 & \\
\hline
\end{tabular}

the work in the following six months, again supporting the learning and confidence about putting that learning into use, identified at the demonstration event. Notwithstanding this, 15 others who recorded that they planned to thin after the event did not. The majority of the remaining respondents described their forests as still being too young to thin and some were not planning any intervention due to concerns about increased windthrow risk, the unproductivity of the forest or the difficulty of accessing the forest. It should be noted that in Ireland there can be a time lag of up to two or three years between making the decision to thin and being in a position to approach timber buyers, having received a licence to thin and carried out the necessary access and preparatory work.

Although only one respondent indicated that they had not thinned due to a lack of information, 16 of the respondents who had not thinned indicated that they would seek more information before thinning, suggesting that they might not be fully confident about putting their knowledge into use. This again supports the need for extension interventions to target owners at specific stages that match their immediate needs. As thinning is related to the age of the forest, the average age of the forest is presented in Table 3 for each respondent type. Although issues such as productivity and stocking will strongly influence the age of first thinning, the results suggest that forest owners are likely to be making the correct silvicultural decision. Teagasc advise that first thinning of Sitka spruce forests (which was the species that comprised the forests of the respondents) can occur between the ages of 13 and 24 depending on productivity levels (Teagasc, 2016).

When the sample is divided into those who had subsequently thinned or were planning to thin in the next 6 months and those who have not thinned there is some indication that the latter group had a lower self-reported understanding of many of the issues covered in the demonstration prior to the event. This difference is not seen in the "After" rating reported in Table 4, which suggests a successful knowledge transfer event. This analysis highlights two things. First, the fact

Table 4

Self-reported understanding levels pre- and post-event for owners who had thinned or plan to and those who have not.

\begin{tabular}{|c|c|c|c|c|c|c|}
\hline \multirow[t]{2}{*}{ Issue } & \multicolumn{2}{|c|}{ Not thinned } & \multicolumn{2}{|c|}{ Thinned } & \multirow{2}{*}{$\begin{array}{l}\text { P-value } \\
\text { before }^{\text {a }}\end{array}$} & \multirow{2}{*}{$\begin{array}{l}\text { P-value } \\
\text { after }^{\mathrm{a}}\end{array}$} \\
\hline & Before & After & Before & After & & \\
\hline $\begin{array}{l}\text { Access - internal and } \\
\quad \text { external }\end{array}$ & 1.9 & 3.9 & 3.0 & 4.0 & 0.115 & 0.334 \\
\hline Felling licences & 1.8 & 4.0 & 3.0 & 4.5 & 0.046 & 0.137 \\
\hline $\begin{array}{c}\text { Basic pre-thinning } \\
\text { measurement }\end{array}$ & 1.5 & 3.5 & 2.8 & 3.9 & 0.041 & 0.370 \\
\hline $\begin{array}{l}\text { Harvesting - } \\
\text { operational issues }\end{array}$ & 1.9 & 3.9 & 2.7 & 3.7 & 0.225 & 0.544 \\
\hline Timber categories & 1.7 & 3.9 & 2.6 & 4.1 & 0.091 & 0.577 \\
\hline Timber security & 1.4 & 3.4 & 2.4 & 3.8 & 0.012 & 0.592 \\
\hline $\begin{array}{l}\text { Marketing and selling } \\
\text { timber }\end{array}$ & 1.3 & 3.2 & 2.5 & 3.8 & 0.015 & 0.350 \\
\hline $\begin{array}{l}\text { How to go about } \\
\text { thinning your forest }\end{array}$ & 1.5 & 3.9 & 3.1 & 4.5 & 0.003 & 0.118 \\
\hline $\mathrm{N}$ & 18.0 & & 8.0 & & & \\
\hline Ave. forest age & 16 & & 16.6 & & & \\
\hline
\end{tabular}

${ }^{a}$ Wilcox signed ranks test.
Table 5

Differences in forest and owner characteristics between thinned and unthinned forests in NFS 2012.

\begin{tabular}{|c|c|c|c|}
\hline \multirow[t]{2}{*}{ Variable } & \multirow{2}{*}{$\begin{array}{l}\text { Thinned } \\
\text { Mean }\end{array}$} & \multirow{2}{*}{$\begin{array}{l}\text { Unthinned } \\
\text { Mean }\end{array}$} & \multirow[t]{2}{*}{ P-value } \\
\hline & & & \\
\hline Forest Area $^{a}$ & 14.72 & 10.7 & 0.151 \\
\hline Forest Age ${ }^{\mathrm{a}}$ & 18.7 & 12.8 & 0.002 \\
\hline Soil group $(1-3)^{\mathrm{a}}$ & 1.29 & 1.66 & 0.063 \\
\hline Land owned (ha) ${ }^{\mathrm{a}}$ & 81.58 & 67.58 & 0.286 \\
\hline Married (1-yes, $0-$ no) ${ }^{\mathrm{b}}$ & 0.79 & 0.80 & 0.913 \\
\hline Age (years) ${ }^{\mathrm{a}}$ & 58.56 & 54.47 & 0.174 \\
\hline Gender (1-male, 0 -female ${ }^{b}$ & 1.00 & 0.94 & 0.337 \\
\hline Household size $(\mathrm{n})^{\mathrm{a}}$ & 3.29 & 3.34 & 0.898 \\
\hline Formal agri. training (1-yes, 0 -no $)^{\mathrm{b}}$ & 0.71 & 0.70 & 0.952 \\
\hline Part-time farm $(1-\text { yes, } 0-\text { no })^{\mathrm{b}}$ & 0.53 & 0.41 & 0.547 \\
\hline Family farm income $(€)^{\mathrm{a}}$ & $50,735.26$ & $34,707.84$ & 0.233 \\
\hline Cattle/sheep (1-yes, 0-no) ${ }^{\mathrm{b}}$ & 0.47 & 0.53 & 0.670 \\
\hline $\mathrm{N}$ & 17 & 68 & \\
\hline
\end{tabular}

a Mann-Whitney-Wilcoxon test.

${ }^{\mathrm{b}}$ Chi-squared test.

that some attendees already possessed good understanding levels before attending the event and that these participants may have already been in the process of organising the thinning of their forest. Second, it suggests that a certain threshold critical level of knowledge about thinning is required before action takes place.

\subsection{NFS 2012 sample}

Only $11 \%$ of the farmers in the 2012 farm survey had planted forests giving a forest owner sample of 85 . Amongst this group 17 (20\%) had thinned their forest. As shown in Table 5, there was little difference between the farm and farmer characteristics of the forest owners who had thinned and those who had not. On the basis of agricultural extension studies previously undertaken in Ireland, which had shown that farm and farmer characteristics such as farm size, farm system, soil type, farmer age, marital status and education levels have an impact both on the level of participation/adoption of new practices (e.g. Cawley et al., 2015; Hennessy and Heanue, 2012) significant differences were anticipated between those farmers that had thinned and those that hadn't on the basis of these variables; however this was not the case for the forest owners in the NFS. Forest age was the only variable found to be significantly different between the two groups with the average age of thinned forests being 19 years. The age of unthinned forests, 13, again suggests that owners are not making incorrect silvicultural decisions thus far. Interestingly, soil group, a three point scale of general land productivity with 1 being the most productive, differed but was not found to be significant at a $5 \%$ level. Although this variable would be expected to reflect productivity it relates to the whole farm rather than that of the forests alone. Similarly, while the average family farm income was higher for those farms that had planted, the difference was not statistically significant. The motivations for planting forests of these two groups, such as the use of marginal land or future timber income, were also compared but no statistically significant differences were identified and, for brevity, the results are not reported. This is also a surprising result and again suggests that forest age may be dominating silvicultural options and hence owner decision making to date.

Owners were asked why they had not undertaken thinning and forest age was again noted as the primary reason amongst this cohort (Table 6). Only $6 \%$ of respondents indicated that uncertainty around how to undertake thinning was the primary reason for not having thinned. However, this does not include owners who are aware that their forest is currently too young but may face knowledge challenges in the future. 
Table 6

Reasons for not having thinned for NFS 2012 sample.

\begin{tabular}{lll}
\hline Reason & $\mathrm{N}$ & $\%$ \\
\hline Forest too young & 45 & 66.18 \\
Not profitable due to size & 9 & 13.24 \\
Not sure how to thin & 4 & 5.88 \\
Forest is unstable & 2 & 2.94 \\
Timber is better from unthinned forests & 1 & 1.47 \\
No answer & 7 & 10.29 \\
Total & 68 & 100 \\
\hline
\end{tabular}

\section{Discussion}

Significant uncertainty surrounds the motivations and management intentions of new, private forest owners in Europe. This presents a challenge to the implementation of forest policies that require management interventions and to forecasting the flow of ecosystem services from private lands. Although generally smaller in size than industrial forests, NIPFs are major sources of timber in many countries and, as a result, there is significant interest in understanding their management practices and goals (Vokoun et al., 2006). The ambitious goals of Irish forestry policy, including the expansion of forest cover and a significant increase in timber production from private forests, are predicated on the engagement of private landowners, not only with the idea of planting land but also in managing it for timber production. Policy makers wishing to support management practices on NIPF can employ financial incentives, regulatory restrictions or extension services or a combination of the three, each of which have their own strengths and weaknesses. However, in order to understand forest owner's management practices it is important to gain insight into their knowledge requirements and the conditions of their forests. Policies and programs that fail to address the requirements of owners are unlikely to be successful even where financial incentives are offered for desirable management practices (Serbruyns and Luyssaert, 2006; Kilgore et al., 2007). Also, management practices cannot be understood in the absence of knowledge of the silvicultural requirements of the forest.

There are few published examples of extension studies that explore the management outcomes of individual interventions. In a US study tracking owners who were invited to participate in an outreach initiative, McCuen et al. (2013) observed few changes over a six month period although a small number of owners engaged with forestry professionals and developed management plans after engaging with the effort. That study also found that owners who were spatially separated from their properties, absentee owners, and those with smaller farms were more likely to participate in the outreach initiative. In a large scale US study, Kilgore et al. (2015) found that owners who had engaged with some form of assistance, management plans, cost-share or advice, were more likely to have engaged in active forest management and to harvest timber than those who had not. Evaluation studies of forestry extension methods carried out in Mississippi by Londo and Monaghan (2002), found intensive forest workshops which included follow-on reports, to be particularly effective. This is corroborated by Teagasc forestry extension advisers who have expressed the view that owners are more confident in adopting technologies once they have seen the technology being demonstrated. Survey respondents at the thinning demonstration also reported that they found the event 'useful', 'informative', 'valuable' and it enabled them to 'meet other owners' and 'compare forests. For 'new' forest owners, this element of social or peer learning is an important component of extension which is being developed in the form of adviser facilitated forest discussion and producer groups. This study highlights the importance of extension services in promoting active management practices amongst new forest owners but also the necessity to understand these practices in the context of forest stage. The survey conducted at the demonstration and subsequent phone survey show that the majority of participants went on to install inspection paths in their forests, a key practice that facilitates future inventory and thinning. A significant number had also thinned their forest or were planning to thin in the immediate future. Amongst those who had yet to thin, the majority believed that their forest was too young and the information available on forest age confirmed this to be the case.

The study identified a significant positive increase in subjective measures of understanding before and after the demonstration event across the sample. The pre-event responses were found to differ between owners who had, or planned to thin, and those who had not. However, these differences disappeared after the demonstration, indicating a successful knowledge transfer intervention. The differences in forest age suggest that owners with forests closer to thinning stage may have already started the process of gaining knowledge, possibly from attending previous demonstration events, to assist them in their decision making. However, although plausible, this study cannot say anything definitive about cumulative knowledge and management capacity building from previous events, although this could be a focus for future research. In addition, most owners who had not thinned, indicated that they would seek out additional advice before engaging in active management, suggesting that knowledge formation and management capacity building is an ongoing and evolving process. This follows work that was previously undertaken in Ireland which identified a significant lack of forest management knowledge amongst private forest owners (Maguire et al., 2010). However, Blanco et al. (2015) propose that forest owners with productionist objectives may not have deep knowledge of forest management based on a meta-analysis study. Thus, the long term impact of this knowledge gap on timber production is not clear.

The results of the NFS display a lack of significant differences between respondents who had thinned their forests and those who had not, both in terms of forest and owner characteristics and motivation for entering forestry. However, again the importance of forest age is highlighted as it was the only variable that was significant at a $5 \%$ level between the two groups.

Overall, the results strongly suggest that adapting extension interventions and targeting them at owners whose forests are close to the stage of requiring management would result in increased effectiveness and outcomes from extension initiatives. McCuen et al. (2013) concluded that advisory services should be targeted at new owners within the first two years of ownership. From an Irish perspective, as most new forest owners also established the forest it is likely that support will be required before and during planting, essentially the start of ownership. In relation to thinning and harvesting support, this should be targeted in advance of major interventions, such as first thinning.

The results of this study did not find a significant difference between the stated post-event knowledge levels or motivations in the NFS of owners who had undertaken thinning of their forest compared to those who had not. However, there is some evidence that the absolute knowledge levels on critical management issues post-event is higher for those who had thinned their forests. What is confirmed by the study is that management practices in Ireland are critically influenced by the age distribution of private forests. In addition to the significant number of new forest owners, many of Ireland's forests are themselves new. In addition, the translation of forest owners' intentions into actions is a slow process which will probably involve a number of extension interventions including demonstration, hands-on learning, follow-up information and the development of further opportunities for peer learning. Although the results indicate that extension can play a positive role in transferring knowledge and promoting active management, it is likely that gaining an understanding of management practices amongst Irish NIPF owners will only be possible in the coming decade as a significant number of forests reach maturity. Thus, opportunities exist to explore management practices amongst new forest owners as both their own knowledge and their forests develop.

Extension initiatives focused on timber production are the most 
common in Ireland and most Irish forest owners identify economic and production goals as being of most importance to them (Ní Dhubháin et al., 2007). However, the results of this study are relevant to any intervention where the transferral of knowledge relates to active management which can be influenced by forest stage.

It should be noted that attendees at extension events are self-selected by their nature. In this study, invitations were sent to a cohort of owners who lived in proximity to the event and 36 of these ultimately choose to attend. Furthermore only 26 from the 36 attendees completed the follow-up questionnaire. It is acknowledged that this self-selection is likely to have introduced an element of bias. Others have shown that those that attend extension events are often already committed to active management (Langer, 2008). This would suggest that our longitudinal study may have included the owners that are most likely to engage in thinning anyway. Other means of targeting those who are less active may be needed. In addition, the event was targeted at forest owners whose forests had received grant-aid and were approaching the age of first thinning; however, as previously identified, this represents the vast majority of private forest owners in Ireland. Data from the NFS, although a limited sample, does cover a wider selection of owners at a national level. The results from that survey suggest that large numbers of NIPF are at or below the age of first thinning and that this is the defining factor in key management decisions. This is likely to result in a significant increase in demand for extension services in the coming years as owners begin to make decisions about how they will manage their forests. As this study shows, if extension initiatives are targeted, in terms of both forest and owner needs, at the correct audience they can have a positive impact on management decisions by NIPF owners.

\section{Conclusion}

Ireland's new forest owners present a challenge to forest policy goals and extension service providers as they are mainly farmers who benefitted from financial supports to establish their forest and possess relatively low levels of forestry management knowledge. This study highlights the success of a specific intervention in increasing knowledge levels amongst owners and examined the planned and observed undertaking of key management practices. However, it also demonstrates how recognising the management needs of the forest, reflected as age, may be as important as accounting for the needs of the owner. Due to the skewed age distribution of private forests in Ireland, research into NIPF owner decision making is particularly challenging. In the coming years, demand for extension services in Ireland is likely to increase significantly as the private forest estate matures. Through the use of targeted interventions that account for both owner and forest needs, extension service providers can have a positive impact on management outcomes and assist in meeting timber production goals.

\section{References}

Amacher, G.S., Conway, M.C., Sullivan, J., 2003. Econometric analyses of nonindustrial forest landowners: Is there anything left to study? J. For. Econ. 9 (2), 137-164.

Beach, R.H., Pattanayak, S.K., Yang, J.C., Murray, B.C., Abt, R.C., 2005. Econometric studies of non-industrial private forest management: a review and synthesis. Forest Policy Econ. 7 (3), 261-281.

Blanco, V., Brown, C., Rounsevell, M., 2015. Characterising forest owners through their objectives, attributes and management strategies. Eur. J. For. Res. 134 (6), 1027-1041.

Cawley, A.P., Heanue, K., O'Donoghue, C., Sheehan, M., 2015. The Impact of Extension Services on Farm Level Outcomes: An Instrumental Variable Approach. In: Paper prepared for presentation at the 150th EAAE Seminar. October 22-23, 2015. Scotland's Rural College, Edinburgh, Scotland. http://ageconsearch.umn.edu/
bitstream/212664/2/The\%20Impact $\% 20$ of $\% 20$ Extension $\% 20$ Services $\% 20$ on \%20Farm\%20Level\%20Outcomes\%20An\%20Instrumental\%20Variable $\% 20$ Approach.pdf.

Davis, G.A., 2003. Using a retrospective pre-post questionnaire to determine program impact. J. Ext. 41 (4), 1-5.

Duesberg, S., Upton, V., O'Connor, D., Ní Dhubháin, Á., 2014. Factors influencing Irish farmers' afforestation intention. Forest Policy Econ. 39, 13-20.

Follo, G., Lidestav, G., Ludvig, A., Vilkriste, L., Hujala, T., Karppinen, H., Didolot, F., Mizaraite, D., 2016. Gender in European forest ownership and management: reflections on women as "New forest owners". Scand. J. For. Res. 32 (2) (online).

Forest Service, 2013. The Second National Forest Inventory Republic of Ireland Main Findings. (Government of Ireland).

Hennessy, T., Heanue, K., 2012. Quantifying the effect of discussion group membership on technology adoption and farm profit on dairy farms. J. Agric. Educ. Ext. 18 (1), 41-54.

Hogl, K., Pregernig, M., Weiss, G., 2005. What is new about new forest owners? A typology of private forest ownership in Austria. Small-scale For. Econ. Manage Policy 4 (3), 325-342.

Jensen, M.B., Johnson, B., Lorenz, E., Lundvall, B.A., 2007. Forms of knowledge and modes of innovation. Res. Policy 36, 680-693.

Kilgore, M.A., Greene, J.L., Jacobson, M.G., Straka, T.J., Daniels, S.E., 2007. The influence of financial incentive programs in promoting sustainable forestry on the nation's family forests. J. For. 105 (4), 184-191.

Kilgore, M.A., Snyder, S.A., Eryilmaz, D., Markowski-Lindsay, M.A., Butler, B.J., Kittredge, D.B., Catanzaro, P.F., Hewes, J.H., Andrejczyk, K., 2015. Assessing the relationship between different forms of landowner assistance and family forest owner behaviors and intentions. J. For. 113 (1), 12-19.

Kuhns, M.R., Brunson, M.W., Roberts, S.D., 1998. Landowners' educational needs and how foresters can respond. J. For. 96 (8), 38-43.

Kuuluvainen, J., Karppinen, H., Ovaskainen, V., 1996. Landowner objectives and nonindustrial private timber supply. For. Sci. 42 (3), 300-309.

Langer, J., 2008. Family forest owners: insights into land-related stewardship, values, and intentions. In: Report on focus group findings prepared for the sustaining family forests initiative. GfK Roper Public Affairs \& Media, New York.

Londo, A.J., Monaghan, T.A., 2002. Forest owner short courses at the University of Mississippi. J. Ext. 40 (5) (online).

Ma, Z., Kittredge, D.B., Catanzaro, P., 2012. Challenging the traditional forestry extension model: insights from the Woods Forum Program in Massachusetts. Small-scale For. 11, 87-100.

Maguire, K., Ní Dhubháin, Á., Farrelly, N., 2010. The suitability of the private forest estate in Ireland for thinning. Irish For. 67, 21-37.

McCuen, M.E., McGill, D.W., Arano, K.G., Owen, S.F., 2013. West Virginia woodland welcome wagon: design, implementation, and evaluation in three priority areas. J. Ext. 51 (4), 1-12.

Ní Dhubháin, Á., Greene, R., 2009. How much do Irish private forest owners know about forestry? Small-scale For. 8 (3), 249-262.

Ní Dhubháin, Á., Cobanova, R., Karppinen, H., Mizaraite, D., Ritter, E., Slee, B., Wall, S., 2007. The values and objectives of private forest owners and their influence on forestry behaviour: the implications for entrepreneurship. Small-scale For. 6 (4), 347-357.

Ní Dhubháin, Á., Maguire, K., Farrelly, N., 2010. The harvesting behaviour of Irish private forest owners. Forest Policy Econ. 12 (7), 513-517.

Pattanayak, S.K., Murray, B.C., Abt, R.C., 2002. How joint is joint forest production? An econometric analysis of timber supply conditional on endogenous amenity values. For. Sci. 48 (3), 479-491.

Phillips, H., Corrigan, E., McDonagh, M., Fairgrieve, M., Farrelly, N., Redmond, J., Barrett, F., Twomey, M., 2016. All Ireland Roundwood Production Forecast. COFORD, Department of Agriculture, Food and the Marine, Dublin, pp. 2016-2035.

Polanyi, M., 1978. Personal Knowledge. Routledge and Kegan Paul, London.

Serbruyns, I., Luyssaert, S., 2006. Acceptance of sticks, carrots and sermons as policy instruments for directing private forest management. Forest Policy Econ. 9 (3), 285-296.

Teagasc, 2016. First thinning of conifer forests. https://www.teagasc.ie/crops/forestry/ advice/timber-harvesting/first-thinning-of-conifer-forests/ (Accessed 12th July 2016).

van Putten, I., Jennings, S., 2010. Modeling forest owner harvesting behaviour and future intentions in Tasmania. Small-scale For. 9 (2), 175-193.

Virkkula, O., Hujala, T., 2014. Potentials of forestry extension encounters: a conversation analysis approach. Small-scale For. 13 (4), 407-423.

Vokoun, M., Amacher, G.S., Wear, D.N., 2006. Scale of harvesting by non-industrial private forest landowners. J. For. Econ. 11 (4), 223-244.

Wiersum, K.F., Elands, B.H., Hoogstra, M.A., 2005. Small-scale forest ownership across Europe: characteristics and future potential. Small-scale For. 4 (1), 1-19.

Wild-Eck, S., Zimmermann, W., Schmithüsen, F., 2006. Extension for private forest owners - insights from a representative opinion poll in Switzerland. Small Scale For. Econ. Manag. Policy 5 (2), 161-174. 